\title{
Zooming in on labour market cooperation: A study of a failed project to support unemployed young people
}

Lena Strindlund, Madeleine Abrandt Dahlgren and Christian Ståhl

The self-archived postprint version of this journal article is available at Linköping University Institutional Repository (DiVA):

http://urn.kb.se/resolve?urn=urn:nbn:se:liu:diva-162724

N.B.: When citing this work, cite the original publication.

Strindlund, L., Abrandt Dahlgren, M., Ståhl, C., (2019), Zooming in on labour market cooperation: A study of a failed project to support unemployed young people, Social Policy \& Administration.

https://doi.org/10.1111/spol.12566

Original publication available at:

https://doi.org/10.1111/spol.12566

Copyright: Wiley (24 months)

http://eu.wiley.com/WileyCDA/ 


\title{
Zooming in on Labor Market Cooperation: A Study of a failed Project to Support Unemployed Young People
}

\author{
Lena Strindlund, Madeleine Abrandt Dahlgren, Christian Ståhl \\ Department of Medical and Health Sciences, Linköping University, Linköping, Sweden. \\ Correspondence to: Lena Strindlund \\ Department of Medical and Health Sciences, Linköping University, \\ 58183 Linköping, Sweden. \\ Tel: $+46(0) 763774727$ \\ Mail: lena.strindlund@liu.se
}

\section{Abstract}

Purpose: The aim was to study the relational dynamics of interorganizational cooperation over the life of a labor market project supporting unemployed young people.

Methods: The methodological process followed the practice theory toolkit described by Nicolini (2012). Data was collected by ethnographical methods through the initiation, development and closing down of the project. Data analysis was performed in relation to three focus areas: (a) tensions between creativity and normativity, (b) processes of legitimation and stabilization and (c) interactional order.

Results: The results visualized how a lack of consensus and the presence of two divergent rationalities, a coordinating rationality and an empowerment rationality, within the project organization had major influences on the initiation, development and closing down of the project.

Conclusions: The study has, by using a practice theory approach, illuminated the complex dynamics of cooperative projects. The study highlights four central and relative conditions when setting up cooperative projects: (a) to enable open and clear communication, (b) to 
create an adequate structure for the project and clarify assignments and roles in the project organization, (c) to build trustful relationships within the project organization and towards cooperative actors, and (d) to prioritize steering and monitoring in cooperative projects in order to avoid the project deviating from its purpose.

\section{Introduction}

People who belong to vulnerable and disadvantaged groups such as young people, people with a disability, minorities, migrants and early school leavers, stand out as having especially low labor market representation (Dean, 2013). Societies struggle to find strategies to tackle long-term unemployment among these groups and to decrease the number of individuals on public provision (Immervoll H, Broecke S, Carcillo S, Goglio A, Keese M, 2013).

Swedish labor market policy is characterized by a work principle that views work as an obligation rather than a right, meaning that individuals are expected to work for their living rather than passively receiving financial benefits (Junestav M., 2004; Nord T., 2018). This principle governs the labor market services and is manifested in activation strategies as a means for labor market inclusion (Immervoll H, Broecke S, Carcillo S, Goglio A, Keese M, 2013; Panican A. \& Ulmestig R., 2017).

The Swedish labor market services have a dual structure consisting of a national authority, the Public Employment Service, and municipal labor market departments. Apart from these actors, other authorities may be involved as active cooperative actors within the sector, e.g., the municipal social services, the Social Insurance Agency, and county councils. Various strategies have been tried to integrate these different services to improve outcomes for vulnerable groups with complex needs, and to avoid fragmentation and make better use of 
available public resources (Andersson J., 2016; Leary \& Vij, 2012; OECD, 2015). Extensive resources are spent on labor market activation strategies for disadvantaged groups, both within the state and municipal labor market services, and on different integrative efforts (Panican A. \& Ulmestig R., 2017; Svenningsson L., 2006). The municipal labor market service alone engages 4400 employees and activates approximately 100000 participants yearly (Panican A. \& Ulmestig R., 2017).The municipal labor market service has a responsibility for providing vocational rehabilitation for long-term employed and other groups who do not receive support from other authorities. A common goal is to support individuals to become self-sufficient, i.e., not depending on public provision. Despite the extent of the labor market services, research within the area is limited. Little is known concerning the content and effects of the municipal strategies, the design and impact of integrative initiatives or who the participants are (Panican A. \& Ulmestig R., 2017; Thorén, 2012).

Research on service integration or collaborative public management applies a varying nomenclature for describing different forms of integration, and there is no consensus regarding the specific meaning of different terms such as cooperation, collaboration or coordination (Leary \& Vij, 2012). Different authors have suggested different terminologies, where some scholars have suggested a continuum from more fragmented integration approaches (cooperation) to more connected and integrated forms (collaboration) (Keast, Brown, \& Mandell, 2007; Leary \& Vij, 2012). Another variant is to differentiate between integration on different levels (Axelsson \& Axelsson, 2006); horizontal (i.e., between authority officials or similar) and vertical (i.e., between hierarchical levels) integration, where this results in four different types depending on the amount of integration: contracting (little integration on both axes), coordination (high on the vertical axis, low on the horizontal), collaboration (high on the horizontal axis, low on the vertical), and cooperation (high on both 
axes). In this latter terminology, presented in Figure 1, cooperation is the highest form of integration, while the former suggests cooperation to be the least integrated.

(Figure 1 somewhere here)

Since there is a lack of research on the actual practice within integrative services, it is relevant to pay closer attention to local labor market services and how integrative practices are staged and performed. One approach for studying practices in action is practice theory, which is especially useful in order to study what is actually done in the doing of work and how those doing the work make sense of their practices (Nicolini, 2012). The approach enables close-up analyses of multi-faceted, multi-dimensional, relational phenomena. These kinds of analyses provide a possibility to arrive at an in-depth understanding of complex cooperative practices, in our case, a project with the objective of supporting labor market inclusion of unemployed young people.

The aim of this article is to analyze integrative practices over the life of a labor market cooperation project. The focus of the analysis is on the relational dynamics of interorganizational cooperation, and more specifically on how these dynamics emerge and are enacted during the initiation, the development and the closing down of a cooperative project.

\section{The context of the study}

The context of the studied project was a coordinating association in the south of Sweden. A coordinating association is an arena for cooperation between the Public Employment Service, the municipalities, the Social Insurance Agency, and county councils. Through "The Act on Financial Coordination of Rehabilitation Efforts" the actors are able to cooperate financially within welfare and rehabilitation areas and to decide based on local conditions and needs how 
the cooperation will be designed and implemented (Ståhl C., 2010; The Swedish Parliament, 2003). Hence, a coordination association engages in cooperative and coordinating activities, implying that the term coordination association is somewhat misleading.

During 2014 and 2015, the coordinating association discussed the need to develop cooperation services for unemployed young people, which led to a project starting up in autumn 2015, and planned to continue until 2018 with subsequent implementation into regular practice. However, the plans changed and in spring 2017 the board of the coordinating association decided to end the project prematurely.

(Figure 2 somewhere here.)

The organization of the participating project actors is described in Figure 2. The aim was " $t o$ work out a model for integrated cooperation for young people (16-29 years) with a need for coordinated vocational rehabilitation support to reach self-sufficiency." The project aimed at developing methods, thus requiring decisions on what working model and process would best fulfill the aims to the project steering group. Over 20 project goals were set on different levels. At the organizational level, the project aimed to achieve faster and easier handling of cases as well as promoting knowledge exchange between the cooperating actors. At the individual level, the project aimed to improve participants' life situation through shortened processes and measures tailored to the needs and resources of the individual. It was stated that $50 \%$ of the participants should reach self-sufficiency through work or studies and the other $50 \%$ should receive adequate societal services.

The project was evaluated by learning evaluation with an interactive approach (Svensson, Brulin, \& Sjöberg, 2009). The evaluation was conducted by the first and last author who were responsible to follow the project from initiation to the end, and to give continuous feedback on the development of the project concerning various aspects. The evaluation produced two 
internal work reports and one final report, focusing on the startup process, the working method and why the project was closed down (Strindlund \& Ståhl, 2017).

\section{Methods}

Data was collected through ethnographic methods, and analyzed using practice theory.

\section{Practice theory}

Practice theory is a package of theories used for understanding and explaining social and organizational phenomena, constituting several theoretical approaches with different conceptual and historical similarities (Gherardi, 2012; Nicolini, 2012). The method used in this study is based on the theory-method package described by Nicolini (2012). The package has a toolkit approach aiming to encourage the use of several practice theories and methods to enrich our understanding of everything social and organizations. The multifaceted package responds to the principle that the aim of social science is to provide a richer and more nuanced understanding of the world. The method follows three movements: 1) zooming in on the accomplishments of practice, 2) zooming out to discern the relationships in space and time, and 3) producing textual material that enriches the understanding of the studied phenomenon. The toolkit consists of eight focus areas related to different practice theoretical resources that are connected with examples of sensitizing research questions. The areas serve as examples of analytical foci, and can be used in different combinations. These are: Sayings and doings, Interactional order, Timing and tempo, Bodily choreography, Tools, artefacts and mediation work, Practical concerns, Tension between creativity and normativity, and Processes of legitimation and stabilization (Nicolini, 2012).

\section{The methodological process}


The methodological process used in this study followed Nicolini's iterative zooming in and out movements in four steps. The first zooming in was the ethnographic data collection which focused on exploring and recording the practice. Secondly, we zoomed out by describing the material using theoretical concepts. This process was iterative in character where we zoomed in and out to focus on different analytical levels. The third step involved production of textual material, summarizing the analyses into the present article. In a fourth step, we discussed the results in relation to previous research.

\section{Data collection}

Zooming in on the practices was accomplished through ethnographical field work (i.e.

Czarniawska B., 2007). The methodology seeks for in-depth comprehension and is preferably used to scrutinize specific social phenomenon on small samples with narrative descriptions (Higginbottom, Pillay, \& Boadu, 2013). Data is often collected through multiple methods including participant observations of the studied environment over an extended period of time, interviews and document studies (Fetterman, 2010.) Doing ethnographic fieldwork allows the researcher to get close to the studied practice and is sensitive to its material and embodied nature. While ethnographers originally studied whole communities or cultures, there is wide agreement that the methodology is suitable also for exploring sub-cultures or groups within complex pluralistic contexts (Hammersley, 2018).

Data was collected by the first author between autumn 2015 and spring 2017. The project was closely followed throughout the whole process, from staging/planning to closing down. The data material consisted of observations of weekly meetings and steering group meetings, and focus group interviews (in January 2016 and January 2017) with the project staff and staff members in the participating organizations (September-October 2017). Individual interviews were also performed with project staff, project organization actors and participants in the 
project (in April-June 2017). In total, more than 70 observations, nine focus group interviews and 34 interviews were carried out. As a complement, shadowing of one project staff member in relation to four participants was carried out, where the first author attended different meetings with the staff member and the participants. Data from observations and shadowing were documented in field notes and all interviews were recorded and written out verbatim. A compilation of the data collection concerning strategy, focus, documentation method and numbers is presented in Table 1.

(Table 1 somewhere here.)

\section{Data analysis}

The analysis process started with a review of all collected data (field notes, written reflections, documents, transcribed interviews and focus groups). Thereafter, the first author mapped the collected data, in relation to the eight focus areas in Nicolini's (2012) toolkit. The sensitizing questions were used as a guiding tool concerning what data to search for when zooming in. Data was condensed into codes and was thereafter mapped in relation to the eight focus areas, resulting in an extensive documentation of various examples of situations and aspects to analyze. In the next step, all three authors analyzed the full material. Nicolini's toolkit was used as a heuristic device and drew our attention to three of the suggested feasible focus areas for analyses, namely: Tensions between creativity and normativity, Processes of legitimation and stabilization and Interactional order. The areas were chosen as most relevant for the contents of the collected data, both through the number of matching examples in the material, and their explanatory value for highlighting relational dynamics in the project. 
The areas provided sensitizing questions which were asked to the material (Table 2). Using these three focus areas contributed to focus the analysis and resulted in the identification of two divergent rationalities influencing the initiation, development and closing down of the project: a coordination rationality and an empowerment rationality.

(Table 2 somewhere here.)

\section{Textual process}

Studying practices requires both generating understanding about the work and translating such understanding into textual artefacts (Czarniawska B., 1997). In order to do so, a narrative approach was chosen, using three descriptive situations from different phases of the project to illustrate the influence of the two divergent rationalities in relation to the three focus areas. The first situation, The education day, is from the initiation phase and serves as an example of how the rationalities caused Tension between creativity and normativity concerning the choice of working method. The second situation, The brochure, is from the development phase and is an example of how the rationalities affected Processes of legitimation and stabilization. The third situation, The revelation day, is from the closing down phase and is an example of the importance of the divergent rationalities for the Interactional order. The approach has a genealogical orientation, focusing on how the practice emerges and changes over time (Nicolini, 2012). However, the three focus areas are not limited to these examples in the different time phases, but could be seen throughout the whole process.

\section{Discussion}


In the last step of the methodological process, we zoomed out in relation to previous research on service integration. Four conditions, all found in the literature, were identified as having impact on the presence of the divergent rationalities and the emergence, development and closing down of the project, namely structure, communication, trust and steering (Andersson J., 2016; Ansell \& Gash, 2007; Brulin G. \& Svensson L., 2011; de Rijk, van Raak, \& van der Made, 2007; Ståhl C., Andersén Å., Anderzén I., \& Larsson K., 2017).

\section{Results}

\section{Two divergent rationalities}

One of the main results of this study was the identification of two different rationalities that influenced the practice within the project: a coordinating rationality and an empowerment rationality. These represented two divergent logics that contrasted against each other in most respects, e.g., the purpose of and the methodology in the project, and divided the project organization into two groups, each following and acting in accordance with "their" rationality.

\section{The coordinating rationality}

The coordinating rationality was characterized by an idea that the project would develop a coordination model for individuals who are currently circulating in the welfare system. It would facilitate the coordination of support and work rehabilitation services, and thereby save time, money and energy for the individual and the welfare system. The goal according to this rationality was to help individuals reach the right activity, and the target group was both the young people and staff in remitting organizations who needed help with navigation and finding services for their clients. This rationality viewed the project as a short-term coordinating function, where young people were being identified and passed on to a fitting 
activity in existing organizations. The working model was influenced by the Coordinated Individual Plan, which is meeting form with legal support in the Health Care Act and the Social Services Act (Swedish Association of Local Authorities and Regions, n.d.). The design would enable a flow of several hundreds of individuals during the project time, relieving the participating organizations in their regular assignments. According to the coordinating rationality, the staff were expected to be experts at coordinating, and to work $50 \%$ in their home organization and $50 \%$ in the project, in order to create conditions that facilitate cooperation between staff in the organization and the project. The financier and the steering group adhered to this rationality.

\section{The empowerment rationality}

The empowerment rationality was characterized by an idea that the project would develop a model where individuals could be listened to and empowered, aiming to find and help individuals that had been circulating in the welfare system. The target group was identified as individuals with complex problems, where their need for strengthening activities was emphasized with the goal to reach better self-esteem and health. This was seen as a necessary step before working towards self-sufficiency. This rationality viewed the project as an empowerment function where young people were enrolled and strengthened by the project staff, with no limits concerning time and content. The working model was inspired by a cooperative project in another municipality in the north of Sweden. The rationality implied long treatment periods of up to more than a year and the project would consequently be offered to a limited number of individuals. The staff were expected to be experts on personal treatment and work empowerment oriented according to the Motivational Interviewing model (Miller W. R. \& Rollnick S, 2012), and to work full time in the project in order to focus solely on the participants. The focus was on internal cooperation between staff in the project group, 
not on referral staff. The project owner, project leader and the project group adhered to this rationality.

In the next section, three situations from the project are used to illustrate how the two divergent rationalities influenced the emergence, development and closing down of the project. The situations are analyzed in relation to the focus areas: Tensions between creativity and normativity, Processes of legitimation and stabilization and Interactional order (Nicolini, 2012).

\section{Tensions between creativity and normativity}

In the first situation, the influence of the divergent rationalities on Tensions between creativity and normativity is described in relation to one of the main tensions in the project, the choice of working method. In particular, the focus is on the sensitizing questions concerning formal and informal rules, where and how disputes between right and wrong are played out, and in which directions the practice is being stretched.

During the first weeks after starting up the project, the main focus within the project group was to find out what to do and how they were supposed to work. The initial project application did not guide them since it did not contain information about methods or theories that the project was assumed to follow. It also allowed for different interpretations of the aim and which goals to prioritize. The project group turned, without success, to the steering group for answers. At this time, the steering group was not fully present and not engaged in supporting the project group in this work. In interviews, steering group members retrospectively noted that there was widespread uncertainty concerning roles, tasks and responsibilities. 
During a meeting with the financier, during these first weeks of seeking the right method, the project group were told that the project was a 'blank sheet' and that they had free hands to be creative and develop a method within the project. The financier tried to nudge the project in the direction of the coordinating rationality by registering the project group for a one-day course in the Coordinated Individual Plan (Swedish Association of Local Authorities and Regions, n.d.). However, this method was not accepted by the project owner and by some of the project group members, since it was not in line with their perception of the aim of the project. Instead, the project owner encouraged the project leader to consult a company specialized in offering training and guidance in an empowerment-inspired method for the personal treatment of young people, which supported the empowerment rationality of the project.

The following is a description of the education day.

'The education day - the choice that affected everything'

Data from observation.

Scenario: Internal education day, 1 month after project start, November 2015.

The project has been running for a few weeks but the staffing from all participating organizations is not yet complete. The project leader and some of the group members have been working together since the first day, some are new and some are still waiting to join. The project leader is new to the organization and the role of leader, and relies on the project owner and two of the group members who have had a driving role in the project application. 
The atmosphere is expectant. The project leader and the group members have requested guidance from the management on what they are expected to do and how. Now they think they will finally get some answers.

The day consists of exercises aiming at getting to know each other combined with education on the working method of the education company. The method that is being taught is empowerment-inspired and is described as 'world class treatment'. This approach is taught as being obtained by having a 'participant focus' and by using a 'solution focus'. The consultant describes a target group that has been abandoned and is not being listened to. The group is encouraged to switch focus, from being the expert to asking questions and listening to the individual for the solution. The method is described as time consuming but is explained by the argument that this must take time. If questioned by the management, the group members are encouraged to use the motto 'when something seems to go too slow-slow down further'.

Success is to be reached by using the techniques and the approach presented during the day, and by adding more education offered by the company during the project time.

The day ends with a future visualization exercise. The group members get to toast with bubbly and celebrate their project being a success story. The walls are covered with several news headlines reading 'Best in Sweden 2019', 'The new working model' and 'Implemented throughout the country'.

Since the project group was new, its members were easily affected and in need of guidance. The project leader lacked knowledge in the area and relied on the project owner. The project owner and two project group members from the project owners' organization had undergone training with the education company previously and were convinced that the method was the 
right one. They used the same language and expressions as the consultant and contributed by giving the consultant and the method legitimacy.

The method was offered as the answer to the project group's questions. Finally, they were told what to do and how to do it. This was particularly satisfying since the consultant was a convincing expert in both the method and the target group, and offered to support and supervise the group during the process. Moreover, he mediated a clear goal image to them: by following this method they would become a successful project. The consultant gave guidance on what was right and wrong in accordance with the method.

The education day was a crossroads. The normative approach of the consultant contributed to creating tensions between the different rationalities. After this day the project was stretched in a direction of the empowerment rationality, away from the coordinating rationality. It all made sense to the group and since they were told to be creative and fill the 'blank sheet', they were eager to follow the method and begin to accomplish a deed.

Since the steering group at this time had a passive role, this choice of method was given little attention. They did not understand the importance of the direction and how it contributed to a conflict between normativity and creativity, that is, the interpretation of what the project group was supposed to do and within what frames they could be creative.

\section{Processes of legitimation and stabilization}

In the second situation, the influence of the rationalities on Processes of legitimation and stabilization is described from the first pronounced conflict within the project. A particular focus is on how the practitioners identify themselves with their practice and their rationality, what is being said and done and what artefacts are being used for the purpose. 
After the education day, the project group began to work in accordance with the empowerment rationality. Their main intention was to build up a project that was in line with the empowerment method, with an individual focus. The education company had taught them that 'world class treatment' was the success factor. The treatment was described as the staff strengthening the young people by building up close and trusting relationships.

To create conditions for 'world class treatment', the project group spent a lot of time and effort talking about and creating a practice in line with the approach. They wanted the project to be perceived by the young people as "non-authority-like" in order for them to feel welcome and safe. In doing so, they furnished the facilities like a living room, with a TV and free coffee from a coffee machine. New staff were introduced to the empowerment rationality by the existing group and its informal leaders; at weekly meetings, these leaders set aside time to work with tasks from the education company in order to enforce project values. These group exercises and the introduction of the novices contributed to the group growing close and identifying with the practice and its rationality.

The next step in this identification process concerned information and marketing material. For the project group, it was important that they were seen, by both young people and remitting organizations, as a new and unique project that had never existed before. Moreover, they emphasized the importance of not being connected with the remitting organizations.

The following is a description of the first conflict between the project group and the financier, starting with the design of a brochure.

"The brochure" - the first conflict

Data from observations during weekly team meetings.

Scenario: A weekly team meeting in December 2015, two months after project start. 
At this weekly meeting, the project leader informs the group that the financier has offered to create an information brochure, as they do with all their financed projects, based on the project application. The atmosphere is upset. The project group strongly resists and expresses that they want to be in control of this process. 'Why can't they just let us do this by ourselves?', 'They don't know what we are doing here!' The project group is convinced that the financier's information material will not work for their young people, concerning neither content nor design. They encourage the project leader to tell the financier to let go.

After the meeting, the project leader conveys the wishes of the group to the financier. Even though it differs from the financier's routines and causes tension, the project gets permission to create its own information and marketing material.

A consequence of this event was that the project group decided to purchase services from an external PR agency. They designed a logo for the project that they used on marketing material such as pens, sweaters, signs and roll-ups. They also created their own brochure targeting young people and remitting organizations, with their own logo and pictures of young people, containing information about the project inspired by an empowerment approach.

This process can be seen as a way of legitimizing the group's choice of method and their interpretation of the aim of the project. Their identification as a non-authority practice was an essential key to reaching the young people and offering 'world class treatment', and thereby succeeding with the project. In order to do that, artefacts like staff sweaters with logos and a welcoming environment became important and logical strategies. The design of the brochure was therefore central in this legitimizing process as it affected how they were perceived by participants, where they did not want to appear as an authority. The project group often 
recalled to themselves during the weekly meetings that their aim was to work out a new model and this was seen as a strategy to reach that goal.

From the coordinating rationality perspective, the effort that the project team put into legitimizing themselves through their use of artefacts did not make sense. The representatives of the financier did not understand why it was so important for the project team to design their own brochure. Nor did they understand how it could be relevant to put that much effort into creating a non-authority-like environment since the young people, according to their rationality, should only pass through. Moreover, the representatives of the financier reacted to the scope and use of the marketing materials and why the project printed logos on pencils and other marketing materials attracting the young people instead of reaching out to colleagues at the remitting organizations who needed to know about the project in order to remit young people. These concerns from the financier concerning the marketing budget resulted in a written notification to the project owner and the project leader. The brochure conflict escalated to include the whole project economy.

\section{Interactional order}

In the third situation, the influence of the two rationalities on Interactional order is described from a planning day where the divergent rationalities were finally revealed. There is a particular focus on the different positions within the interactional order concerning power shifting, authority reclaiming and grouping processes.

During the period after the brochure conflict, a split grew between the actors relating to the two different rationalities, paving the way for a power struggle. On the empowerment side there was the project owner, allied with the project leader and the project group. On the 
coordinating side there was the financier. In between was an unattended and absent steering group, unaware of what was going on.

The project group and the project leader developed a strong loyalty to the project owner and followed this distancing towards the financier. They questioned the financier's role, at times even ridiculed them, and questioned the financier's attempt to influence the project in a coordinating direction.

The project owner ran the project in accordance with the empowerment rationality. Apart from promoting the education company which contributed to the choice of the empowerment approach, she also supported the creating of the environment and the marketing materials in line with the empowerment approach. These were decisions questioned by the financier. As a strategy to minimize the financiers' opportunities to influence the project she managed to exclude the financier from the steering group, which effectively made it possible for the project owner to control the project. The financier observed the project from a distance and made several attempts to influence the development in a coordinating direction, e.g., by repeatedly suggesting the Coordinated Individual Plan as a working method, and by questioning the low number of participants going through the project. None of these attempts were taken into account by the steering group. However, the project owner became subject to an investigation within the municipality for financial irregularities, resulting in the project owner being replaced in December 2016, and was replaced by a new project owner with a good relationship with the financier, and who shared the coordinating rationality. The financier was then invited back to the steering group.

In January 2017, the steering and project groups had a joint planning day. The aim for the day was to get the steering group and the new project owner engaged in the project and to reach consensus concerning the planning of the remaining two years of the project. 
The following is a description of a planning day where the actors meet for the first time in the new project organization constellation.

\section{The revelation day - the beginning of the end}

Data: Participative observation

Scenario: A planning day for the new project organization, January 2017, more than one year after the start.

Several steering group members are missing from the meeting. The project group members express frustration at the managers' lack of interest in the project. 'How are we going to get consensus when they don't even bother to show up?'

The first point on the schedule of the day is feedback from the researcher responsible for the ongoing evaluation of the project. This point has been questioned by the project group and the project leader who want the planning day to be their day, without influence from the researchers. This request is not affirmed and the researchers are invited to present a report focusing on the project's working methods. The researchers had captured the project group's description of the project, in their own words, presented as a logical model of the links between the target group, the offered activities and the expected goals. They had also performed group interviews with staff at remitting organizations concerning their perceptions of the project.

The presentation shows that the group have focused on aspects supporting the empowerment-inspired approach such as 'participant focus' and 'world class treatment', and the importance of offering a non-authority-like environment. Activities related to the original aim from the project application, to coordinate young people through the welfare system, are not seen in the model, and nor are the original project 
goals of reaching $50 \%$ of participants working or studying. Instead, the model suggests stopping enrollment since the young people need long enrollment periods of more than a year.

After the presentation, the steering committee and project group are separated to discuss how to proceed. The members of the steering committee are surprised at the logical model and expresses concern at the development towards an empowerment rationality, in an opposite direction from the aim. 'I thought we had created a coordinating practice. But this is something completely different'.

The planning day came as a revelation to the steering committee. The presentation of the logical model of the project made the empowerment rationality pronounced. The present members of the committee, including the new owner and the financier, became aware of the development of the project in a direction that deviated from the main aim.

The steering group had not taken responsibility for the project's development, which had given the project owner the power and the opportunity to usurp the project together with the project leader and the project group. The lack of steering and other shortcomings in the project (such as a lack of anchoring, conflicts between the owner and the financier and a diffuse project application), created conditions for the project owner to steer the project in a direction in accordance with the empowerment rationality. As a consequence, the project group had developed a strong group feeling enforced by the processes of legitimation and stabilization. The lack of support from the steering group had made them rule the project themselves, and became personally engaged in promoting the empowerment rationality. 
The planning day induced a power shift. The steering committee became aware of the need to reclaim authority and take responsibility for the steering and the continuation of the project. They were self-critical and recognized that they had failed in their responsibilities. The planning day was followed by an intense period with meetings, both within the steering group and in dialogue with the project leader and the project group, on how to continue. The two rationalities were put against each other and three different alternatives were discussed: letting the project continue during the remaining two years of the project time, getting the group to change direction towards a coordinating project, or closing it.

The first alternative was the only option for the project group. This was however not an alternative for the steering committee since it did not comply with the original aim. Alternative two, to change direction in line with a coordinating rationality, generated strong reactions from the project group and the project leader since they identified strongly with the empowerment rationality and saw no gains in changing perspective. They questioned the sudden presence of the steering groups and did everything in their power to prevent their interference and obstruct the process. These protests spurred mistrust from the steering group, which decided to go close down the project.

The decision was followed by a turbulent period, where lack of communication and mistrust between the two sides complicated the closing down process and solidified the conflict. The project leader was replaced by a representative from the financier and the project group was given four months to end their ongoing cases. The decision was never accepted by the project group and they spent the rest of the time in the project questioning the decision, trying to make sense of the development.

"If they wanted us to work in another direction - why didn't they steer us in that direction?" (Interview with a project group member, during the closing down process) 


\section{Discussion}

The aim of this article was to study the relational dynamics of interorganizational cooperation over the life of a labor market cooperation project. The results show a project characterized by two divergent rationalities, a coordinating rationality and an empowerment rationality, which had major impact on the emergence, development and closing down of the project. In order to understand the dynamics behind the emergence, development and closing down, we will in this section discuss the results in relation to four conditions identified in previous literature, namely: structure, communication, trust and steering.

The first condition, communication, has been highlighted in previous research within cooperation as a prerequisite to reach the intended aims (Ansell \& Gash, 2007). In order to reach stabilization in a practice, Gherardi (2012) claims that practitioners need to negotiate and discuss what is good practice, how it can change and improve or whether it should be discarded. Hardy et al. (Hardy, Phillips, \& Lawrence, 1998) argues that communicative processes in interorganizational settings serve to develop shared meanings as a foundation for non-opportunistic behavior, where the existence of conflicts should be understood as a sign that all partners contribute to the creation of a shared meaning; hence, purposeful communication is the vehicle to manage differing opinions and to build consensus. The importance of consensus in different aspects between cooperating actors has been emphasized in several studies. Huxham (2003) points out that cooperation practices often are characterized by a variety of organizational and individual agendas making it difficult to agree on aims in practice. De Rijk et al. (de Rijk et al., 2007) emphasizes the importance of actors' goals in understanding actors' will and ability to cooperate and stresses that goals can seem similar on the surface but be quite divergent when studied in more detail. Similarly, Ståhl 
(2010) concluded that consensus is often expected by participating organizations, but that such expectations may serve to hide underlying conflicts which will come into play in the day-to-day practice, and which may contribute to undermining the conditions for purposeful cooperation.

The second condition, structure, have been highlighted in previous research as being important concerning successful project management and interorganizational cooperation (Andersson J., 2016; Ansell \& Gash, 2007; Brulin G. \& Svensson L., 2011; Huxham, 2003). Svensson \& Brulin (2011) emphasize the importance of structure by defining roles, tasks and responsibilities in project organizations in order to reach stabilization and sustainability. Huxham (2003) points out how ambiguous membership structures in cooperation may lead to inertia and serve to undermine motivations for achieving the intended ends. Andersson (2016) shows how legislation may influence structures, where the specific form of cooperation through coordination associations tends to lock cooperation into projects and specific organizational forms, which may be suboptimal for meeting the stated aims.

The third condition, trust, has also been pointed out as a central condition for cooperation in previous research. Trust has been described both as a result of well-functioning cooperation and a prerequisite for such cooperation (Ansell \& Gash, 2007). Huxham (2003) points out that a lack of trust is often the starting point in various cooperations, since the structures often do not allow the partners to choose whom to work with. De Rijk et al. (2007) emphasize the cooperation actors' perceptions of others as an important aspect in understanding the will to collaborate and the actors' dependence on each other. In practice, trust works as a moderator between cooperative motives and behavior, where it needs to be present to translate the former into the latter (Dirks \& Ferrin, 2001). Hence, trust and distrust are reinforcing processes, where distrust may become a downward spiral, which after a certain threshold is 
passed may become destructive and prevent cooperation and organizational learning (Luhmann, 1979).

The fourth condition, steering, has been stressed in previous research in interorganizational cooperation and is often mentioned in relation to the other conditions above (e.g. (Ansell \& Gash, 2007; Brulin G. \& Svensson L., 2011; Huxham, 2003). Huxham (2003) highlights the importance of management for cooperational practices due to the inherent difficulties with collaborative practices and the importance of steering the project in line with the aim and purpose. It is also reasonable to assume that leadership plays an important role in collaborative structures in managing the relationships between different actors, and in establishing a communication climate that manages to overcome conflicts (Hardy et al., 1998).

During the emergence of the project, as illustrated in the results through Tensions between creativity and normativity and the "Education day" situation, the communication was from the very start characterized by ambiguity. The project description was insufficient and gave little guidance concerning aim, goal and methods which hampered the setting up of the project. This had consequences for the structure of the project organization. The project idea was not sufficiently anchored in the participating organizations and there were uncertainties concerning each organization's roles. These conditions contributed to the project starting up with an absent and uncommitted steering group. The lack of steering in combination with the loose structure of the project and the lack of written steering documents meant that oral communication, like the call to fill the "blank sheet", had a major impact. This was interpreted as encouragement for the project group to interpret the project idea and act on that interpretation freely. This responsibility given to the project group can be seen as a sign of trust that existed between the parties during this phase; a trust that built on the perception that there was consensus and only one interpretation, one rationality. 
During the developmental phase, as illustrated in the results through Processes of legitimation and stabilization and the "Brochure" situation, the steering continued to be challenging. The lack of structure concerning roles, responsibility and mandate hampered the steering and resulted in an absent steering group which contributed to the steering being executed by informal leaders within the project group, strongly influenced by the external educational company. The communication within the project organization was poor and characterized by misunderstandings and conflicts related to the two rationalities. The project group perceived they had freedom to interpret project goals and reacted strongly when questioned by the financier. It also developed a strong group identification, where it grew closer together and distanced themselves from all actors not supporting the empowerment approach. The consequence of these conditions was a growing distrust between the two parties, and a correspondingly strong trust within the project group in their opposition against the financier. This distrustful climate was characterized by strong group norms where communication from the financier was maliciously interpreted and consequently criticized and sometimes even ridiculed by the project group, with the informal leaders at the forefront. The questioning went both ways and gradually resulted in a conflict.

The closing down process was a reaction to the pronunciation of the two rationalities and the project gliding towards the empowerment direction. The phase was characterized by a communication breakdown where the parties failed to communicate concerning each other's different perspectives. During this phase, febrile communication took place which mostly served to entrench the conflict. The revelation of the different rationalities had consequences for the structure of the project organization and the steering, encouraging the steering group to take leadership and reclaim power from the project group. Another crucial condition in the closing down process was the lack of trust in the steering group due to the history of 
shortcomings during earlier phases, which made it difficult for the project group to accept the power shift. The project group fought for their right to continue the project in line with the empowerment rationality, without success, which strengthened the steering group's lack of trust in the project group and was taken as proof of the impossibility of redirecting the project in a coordinating orientation, thus contributing to the decision to close down the project early.

In sum, the conditions described in previous literature maps well to the experiences of this project, where the model for collaborative governance by Ansell \& Gash (2007) describes similar conditions for maintaining collaborative practices. They specifically point to starting conditions, institutional designs, collaborative processes (involving dialogue and trustbuilding), and leadership, which all influence collaborative outcomes. What our study adds in this respect is not primarily how the managerial level in a cooperation project may have one idea of what levels of integration is meant to be accomplished, which may differ from the opinions of the staff working in the project. Rather, we add how such lack of alignment may not be disclosed due to organizational difficulties. The results show how managerial disinterest in the project provided ample opportunities for the project staff to develop a collaborative practice that was quite distant from the coordinating ideal that was originally planned for. The potential conflict between these rationalities did not come into play until they were explicitly pointed out to the management.

\section{Methodological consideration}

We found the practice theory approach and the toolkit described by Nicolini (2012), with the focus areas and related sensitizing questions, to be a valuable framework for studying, understanding and representing the cooperative practice. The combination of an ethnographic 
method and a narrative design contributed to visualizing the mechanisms and aspects affecting the emergence, development and closing down of the studied project, and thereby visualizing the two different rationalities. These rationalities were not apparent to the project, and was not identified in the initial evaluation reports. The rationalities were a result of a theorizing process (Hammond, 2018) where we used Nicolini’s toolkit as a heuristic tool. Complex social phenomena such as inter-organizational cooperation are built on social interactions. A practice perspective is hence a feasible approach, albeit demanding since it calls for a close affiliation with the studied practice. In our study this was managed through the use of ethnographic methods. This allowed for an analysis of the actual dynamics in the social interactions, rather than having to rely only on accounts given in interviews.

As argued by Gherardi (2012), the method allows a plurality of simultaneous reconstructions of the world because its validation criterion is plausibility, in contrast to the paradigmatic mode that only allows one representation of reality at a time, and where the validation criterion is truth, as in true or false. In this study this mode was especially valuable since it contributed to the finding of the two simultaneously present rationalities.

The learning evaluation approach implied that the researchers were involved in the development of the project. The internal report presented at the planning day contained recommendations of reconciling different views of the project goals and aim. In this sense the researchers had a potential influence over the project, although the decisions made did not follow these recommendations.

The transferability of the study results is limited to similar cooperative projects between authorities, which means the results should be interpreted according to the specific context. However, the ongoing evaluation design, with written reports and continuous dialogue with project management concerning emerging results, increases the trustworthiness of the study. 


\section{Conclusion}

This study contributes understanding of interorganizational cooperation within labor market inclusion strategies. By using a practice theory approach, the study has illuminated the complex dynamics behind the emergence, development and closing down of a cooperation project.

The results have visualized how a lack of consensus and the presence of divergent rationalities can have major influence on project development. We conclude conditions for consensus among participating actors are central when setting up cooperative projects, where we propose four such conditions: 1) to enable open and clear communication, 2) to create an adequate structure for the project and clarify assignments and roles in the project organization, 3) to build trustful relationships within the project organization and towards cooperative actors, and 4) to prioritize steering and monitoring in cooperative projects in order to avoid the project deviating from its purpose. These conditions should not be seen as isolated, but as relative to each other.

The study adds to the knowledge of cooperation dynamics by showing how explicit aims may become second-stage due to dysfunctional internal processes within the project organization; in this case, how such dynamics comprise tensions between creativity and normativity, processes of legitimation and stabilization, and interactional order. Unlike research that raises challenges with cooperation between authority actors, our results show that cooperation was not dependent on authority affiliation, but rather on what type of rationality people within the organizations adhered to. These results add to the literature on labor market integration policies by emphasizing the many difficulties involved in designing and managing cooperative projects, and illustrates how obstacles are related not only to inherent differences 
among participating organizations, but also to interpersonal conflicts that needs to be managed as new organizational forms are established.

\section{Disclosure statement}

The authors report no conflicts of interest

\section{References}

Andersson J. (2016). Locked-in collaboration. Förvaltningshögskolan Göteborg.

Ansell, C., \& Gash, A. (2007). Collaborative Governance in Theory and practice. Journal of Public Research and Theory, November.

Axelsson, R., \& Axelsson, S. B. (2006). Integration and collaboration in public health - a conceptual framework, (1967), 75-88.

Brulin G., \& Svensson L. (2011). Att äga, styra och utvärdera stora projekt. Lund: Studentlitteratur.

Czarniawska B. (1997). Narrating the organization: dramas of institutional identity. (U. of C. Press, Ed.). Chicago.

Czarniawska B. (2007). Shadowing - and Other Techniques for Doing Fieldwork in Modern Societies. Liber.

de Rijk, A., van Raak, A., \& van der Made, J. (2007). A new theoretical model for cooperation in public health settings: The RDIC model. Qualitative Health Research. 
https://doi.org/10.1177/1049732307308236

Dean, A. (2013). Tackling Long-Term Unemployment Amongst Vulnerable Groups. OECD Local Economic and Employment Development (LEED) Working Papers. https://doi.org/http://dx.doi.org/10.1787/5k43jct8n2nv-en

Dirks, K. T., \& Ferrin, D. L. (2001). The Role of Trust in Organizational Settings. Organization Science. https://doi.org/10.1287/orsc.12.4.450.10640

Fetterman, D. M. (n.d.). Ethnography: step by step (2010th ed.). Thousand Oaks, CA: Sage Publications.

Gherardi, S. (2012). How to Conduct a Practice-Based Study. Problems and methods. Edward Elgar Publishing.

Hammersley, M. (2018). What is ethnography? Can it survive? Should it? What is ethnography? Can it survive ? Should it ? Ethnography and Education, 13(1), 1-17. https://doi.org/10.1080/17457823.2017.1298458

Hammond, M. (2018). 'An interesting paper but not sufficiently theoretical ': What does theorising in social research look like ? Methodological Innovations, May-August, 1-10. https://doi.org/10.1177/2059799118787756

Hardy, C., Phillips, N., \& Lawrence, T. B. (1998). Distinguishing Trust and Power in Interorganizational Relations: Forms and Façades of Trust. In Trust Within and Between Organizations. Conceptual Issues and Empirical Applications. https://doi.org/10.1017/CBO9781107415324.004

Higginbottom, G. M. A., Pillay, J. J., \& Boadu, N. Y. (2013). Guidance on Performing Focused Ethnographies with an Emphasis on Healthcare Research Guidance on 
Performing Focused Ethnographies with an Emphasis on, 18(9), 1-6.

Huxham, C. (2003). Theorizing collaboration practice. Public Management Review. https://doi.org/10.1080/1471903032000146964

Immervoll H, Broecke S, Carcillo S, Goglio A, Keese M, S. S. (2013). Activation strategies for stronger and more inclusive labour markets in 620 countries: Key policy challenges and good practices.

Junestav M. (2004). Arbetslinjer i svensk socialpolitisk debatt och lagstiftning 1930-2001. Uppsala University.

Keast, R., Brown, K., \& Mandell, M. (2007). Getting The Right Mix : Unpacking Integration Meanings and Strategies, 7494. https://doi.org/10.1080/10967490601185716

Leary, R. O., \& Vij, N. (2012). Collaborative Public Management Where Have We Been and Collaborative Public Management: Where Have We Been and Where Are We Going?, (October 2017). https://doi.org/10.1177/0275074012445780

Luhmann, N. (1979). Trust and Power. Cooperation without Trust. https://doi.org/10.1177/S0038038501000190

Miller W. R., \& Rollnick S. (2012). Motivational Interviewing. Helping People Change. (Guilford Press, Ed.) (Third Edition).

Nicolini, D. (2012). Practice Theory, Work and Organization. An Introduction. In Practice Theory, Work and Organization. An Introduction. https://doi.org/10.1177/0170840615572590

Nord T. (2018). Arbete som rättighet eller skyldighet. Föreställningar om 
arbetsmarknadsfrånvaro $i$ välfärdsstaten. Karlstad. Retrieved from https://www.divaportal.org/smash/get/diva2:1182964/FULLTEXT01.pdf

OECD. (2015). Integrating Social Services for Vulnerable Groups: Bridging Sectors for Better Service Delivery. In Integrating social services for vulnerable groups: bridging sectors for better service delivery. https://doi.org/10.1787/9789264233775-en

Panican A., \& Ulmestig R. (2017). Lokal arbetsmarknadspolitik. Vem gör vad, hur och för vem? Växjö. Retrieved from http://portal.research.lu.se/portal/files/27446125/LOKAL_ARBETSMARKNADSPOLI TIK.pdf

Ståhl C. (2010). In Cooperation We Trust: Interorganizational Cooperation in Return-toWork and Labour Market Reintegration. Linköping.

Ståhl C., Andersén Å., Anderzén I., \& Larsson K. (2017). Process evaluation of an interorganizational cooperation initiative in vocational rehabilitation: the Dirigo project. BMC Public Health , $11(17$ (1)), 431. https://doi.org/doi: 10.1186/s12889-017-4357-x

Strindlund, L., \& Ståhl, C. (2017). En ingång- Följeforskning, slutrapport (Ongoing research, final report). Retrieved from https://www.samordning.org/images/centrala/dokument/2017/Slutrapport_En_ingang.pdf

Svenningsson L. (2006). Svensk aktiveringspolitik i nordiskt perspektiv. Retrieved from https://www.regeringen.se/49bb33/contentassets/47f03079077c4d1e8003b23afb503bf6/r apport-svensk-aktiveringspolitik-i-nordiskt-perspektiv

Svensson, L., Brulin, G., \& Sjöberg, K. (2009). Learning through On-going Evaluation. Lund: Studentlitteratur. 
Swedish Association of Local Authorities and Regions. (n.d.). Samordnad individuell plan (Coordinated Individual Plan). Retrieved from https://skl.se/halsasjukvard/kunskapsstodvardochbehandling/samordnadindividuellplansi p.samordnadindividuellplan.html

The Swedish Parliament. (2003). Lag om finansiell samordning av rehabiliteringsinsatser (2003:1210)(The Act on Financial Coordination of Rehabilitation Efforts). Retrieved from https://www.riksdagen.se/sv/dokument-lagar/dokument/svenskforfattningssamling/lag-20031210-om-finansiell-samordning-av_sfs-2003-1210

Thorén, K. (2012). Kommunal arbetsmarknadspolitik- en kunskapsöversikt över åtgärder för arbetslösa socialbidragstagare. Stokholm. 


\section{Tables}

Table 1

\begin{tabular}{|c|c|c|c|c|}
\hline Data collection & Focus & Documentation & Time aspect & Numbers \\
\hline $\begin{array}{l}\text { Weekly observations of project } \\
\text { staff meetings and monthly } \\
\text { observations of steering group } \\
\text { meetings. }\end{array}$ & $\begin{array}{l}\text { Documenting meetings and developments } \\
\text { in the project, who is doing and saying } \\
\text { what, what questions are being raised, etc. }\end{array}$ & $\begin{array}{l}\text { Continuous field notes } \\
\text { and written down } \\
\text { reflections }\end{array}$ & During all phases & $>70$ occasions \\
\hline $\begin{array}{l}\text { Informal interviews with actors } \\
\text { in the project organization. }\end{array}$ & $\begin{array}{l}\text { Everything related to the project, from } \\
\text { smaller to bigger issues. }\end{array}$ & $\begin{array}{l}\text { Written down field notes } \\
\text { and reflections from } \\
\text { various informal } \\
\text { conversations. }\end{array}$ & During all phases & $>50$ occasions \\
\hline $\begin{array}{l}\text { Focus group interviews with } \\
\text { project staff members at two } \\
\text { occasions. }\end{array}$ & $\begin{array}{l}\text { No. 1: Expectations of the project and } \\
\text { perceptions of the projects' aim and goal } \\
\text { and their own role. } \\
\text { No. 2: Describing other perception of the } \\
\text { program theory of the project. }\end{array}$ & Transcribed verbatim. & $\begin{array}{l}\text { No.1: Beginning of } \\
\text { development phase } \\
\text { (Jan. 2016) } \\
\text { No. 2: The end of } \\
\text { development phase } \\
\text { (Jan. 2017) }\end{array}$ & $\begin{array}{l}\text { No.1: } 2 \text { focus groups, } \\
9 \text { informants } \\
\text { No.2: } 2 \text { focus groups, } \\
11 \text { informants }\end{array}$ \\
\hline $\begin{array}{l}\text { Focus group interviews with } \\
\text { staff members external to the } \\
\text { project. }\end{array}$ & $\begin{array}{l}\text { Expectations and perceptions of the } \\
\text { project and how cooperation and } \\
\text { communication between the actors } \\
\text { worked. }\end{array}$ & Transcribed verbatim. & $\begin{array}{l}\text { Development phase } \\
\text { (September-October } \\
\text { 2016) }\end{array}$ & $\begin{array}{l}5 \text { focus groups with a } \\
\text { total of } 22 \text { informants }\end{array}$ \\
\hline Shadowing & $\begin{array}{l}\text { Shadowing a project staff member in } \\
\text { relation to } 4 \text { participants and their process } \\
\text { through the project. Participating at } \\
\text { different meetings between the participant } \\
\text { and the staff member. }\end{array}$ & $\begin{array}{l}\text { Document studies, field } \\
\text { notes from observations } \\
\text { at meetings. }\end{array}$ & $\begin{array}{l}\text { Development phase } \\
\text { (Autumn 2016) }\end{array}$ & $\begin{array}{l}1 \text { staff member and } 4 \\
\text { informants }\end{array}$ \\
\hline Document studies & $\begin{array}{l}\text { Studies of various written documents such } \\
\text { as project plan, project application, email } \\
\text { conversations etc. }\end{array}$ & $\begin{array}{l}\text { Written documents and } \\
\text { e-mail conversations. }\end{array}$ & During all phases & $>40$ documents \\
\hline $\begin{array}{l}\text { Formal interviews with actors } \\
\text { in the project organization } \\
\text { (Project group members and } \\
\text { Steering group members). }\end{array}$ & $\begin{array}{l}\text { Their perceptions of the project and } \\
\text { reasons for closing down. }\end{array}$ & Transcribed verbatim. & $\begin{array}{l}\text { Closing down phase } \\
\text { (April-June 2017) }\end{array}$ & $\begin{array}{l}17 \text { interviews }(9 \\
\text { project group members } \\
\& 8 \text { steering group } \\
\text { members) }\end{array}$ \\
\hline $\begin{array}{l}\text { Interviews with participants } \\
\text { (Youths) }\end{array}$ & $\begin{array}{l}\text { The youth's perception of the project and } \\
\text { the support they had received. }\end{array}$ & Transcribed verbatim. & $\begin{array}{l}\text { Closing down phase } \\
\text { (April-June 2017) }\end{array}$ & 17 interviews \\
\hline
\end{tabular}


Caption Table 1: A compilation of the data collection in the project

Table 2

\begin{tabular}{|c|c|c|}
\hline $\begin{array}{l}\text { Tensions between creativity } \\
\text { and normativity }\end{array}$ & $\begin{array}{l}\text { Processes of legitimation } \\
\text { and stabilization }\end{array}$ & Interactional order \\
\hline $\begin{array}{l}\text { How are breakdowns } \\
\text { addressed? Where and how are } \\
\text { the disputes between right and } \\
\text { wrong played out? Where are } \\
\text { the main tensions? And what } \\
\text { about the formal and informal } \\
\text { rules? In which directions is the } \\
\text { practice being stretched? }\end{array}$ & $\begin{array}{l}\text { Do the practitioners use the } \\
\text { practice to identify themselves } \\
\text { as a community? How is the } \\
\text { difference between insiders and } \\
\text { outsiders brought to bear? How } \\
\text { are practices made durable? } \\
\text { What doings, sayings and } \\
\text { artifacts are employed for the } \\
\text { purpose? }\end{array}$ & $\begin{array}{l}\text { What sort of interactional order } \\
\text { is performed by this specific } \\
\text { practice? What positions does } \\
\text { this specific practice make } \\
\text { available? How are these } \\
\text { positions negotiated or } \\
\text { resisted? How are asymmetries } \\
\text { and inequalities produced or } \\
\text { reproduced in the process? }\end{array}$ \\
\hline
\end{tabular}

Caption Table 2: The three chosen focus areas and examples of sensitizing questions for zooming in (Nicolini, 2012, p. 220). 


\section{Figures}

Figure 1:

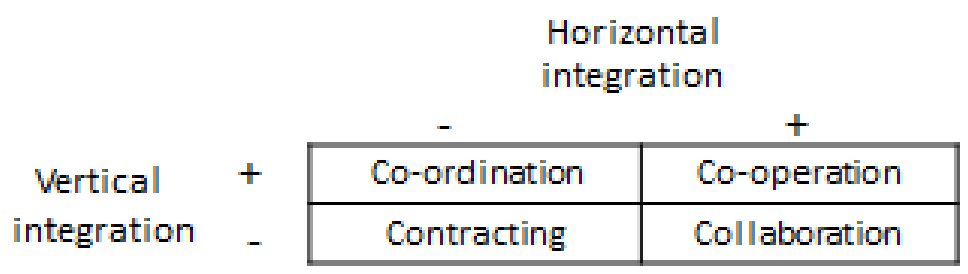

Caption Figure 1: Conceptual scheme of different forms of integration (Axelsson \& Axelsson, 2006)

Figure 2:

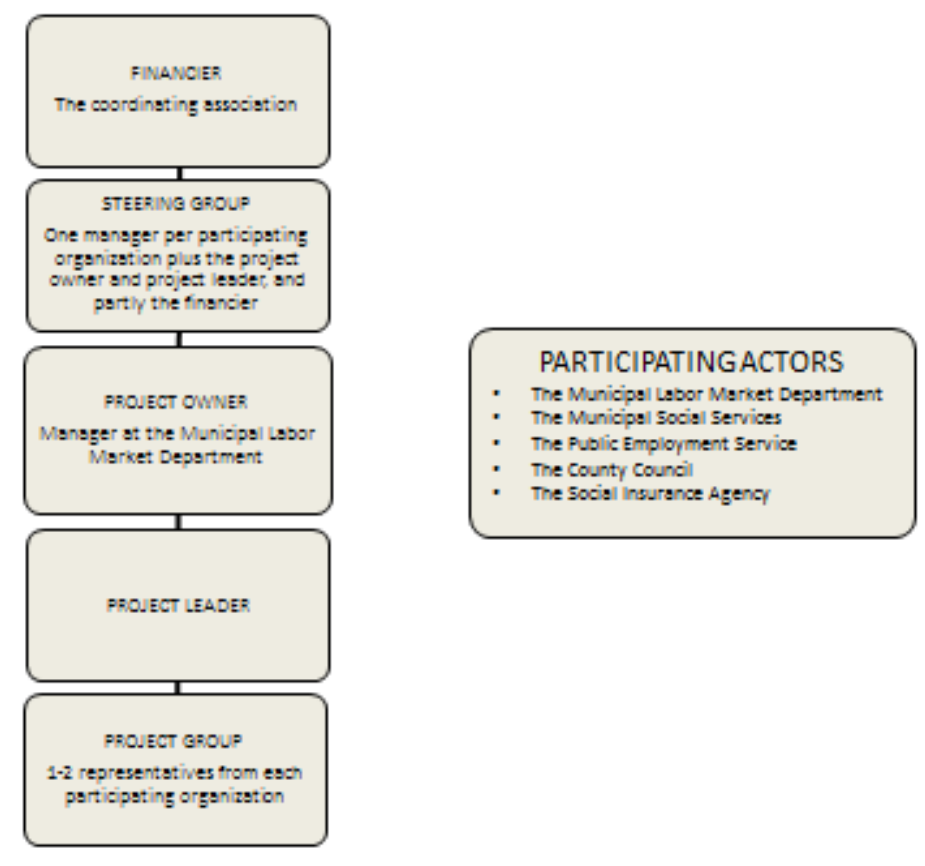

Caption:

Figure 2: The organization of the participating project actors 